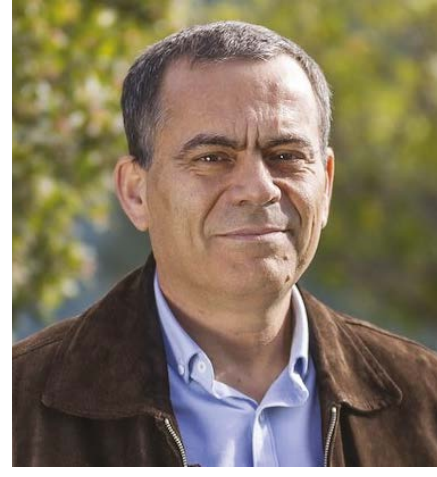

\section{Artur Silva Reeleito para o Conselho Executivo da EuChems}

Artur Silva, Presidente da Sociedade Portuguesa de Química (SPQ), Vice-Reitor da Universidade de Aveiro (UA), e Professor Catedrático do Departamento de Química desta universidade foi reeleito para o Conselho Executivo da EuChems, após uma primeira eleição em 2016.

Além de Artur Silva, foram ainda eleitos para o mesmo órgão Renáta Oriňaková e Christophe Copéret. Renáta Oriňaková é Professora e Diretora do Departamento de Físico-Química do Instituto de Química da Faculdade de Ciências na Universidade Pavol Jozef Šafárik em Košice, Eslováquia. Atualmente, é Vice-Reitora da Faculdade de Ciências para a área de ciência, investigação e desenvolvimento. Christophe Copéret é Professor no Departamento de Química e Biociências Aplicadas da ETH Zürich desde novembro de 2010.

A eleição decorreu durante a Assembleia Geral da EuChemS que teve lugar a 24 setembro de 2020. 0 mandato teve início a 1 de janeiro de 2021.

Bruno Machado

brunofm@fe.up.pt
O Prémio Luso-Espanhol Conferencia Lourenço-Madinaveitia 2020, instituído pela Sociedade Portuguesa de Química e pela Junta de Gobierno de la Real Sociedad Española de Química, foi atribuído ao Professor Tomás Torres Cebada, da Universidade Autónoma de Madrid, em reconhecimento do seu trabalho e impacto na comunidade científica, além do seu contributo para a colaboração entre Portugal e Espanha no domínio da Ciência. 0 prémio é atribuído anualmente, e em alternância, a químicos portugueses e espanhóis com projeção internacional. A lista de todos os premiados pede ser encontrada na página da SPQ em spq.pt/ premios/luso-espanhol/lista.

\section{Bruno Machado}

brunofm@fe.up.pt

\section{Prémio Luso-Espanhol Conferencia Lourenço- Madinaveitia 2020}

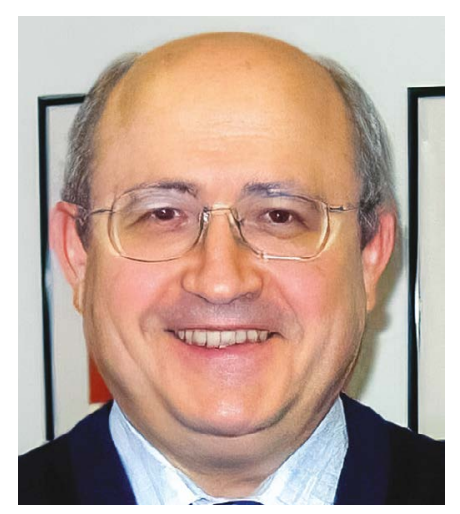

